\title{
Terminal disinfection of infant feeds
}

\author{
K. E. A. HUGHES, E. M. DARMADY, AND S. E. DREWETT \\ From the Central Laboratory, Portsmouth and Isle of Wight Area Pathological Service
}

SYNOPSIS A time and temperature relationship required to destroy certain pathogenic organisms in milk feeds has been ascertained. A method of achieving this destruction by using steam at atmospheric pressure is described, and a routine method for use in milk kitchens is suggested.

Wright (1951) examined some 300 infant feeds prepared by different methods at different places and found that $54 \%$ had colony counts of 500 or more per $\mathrm{ml}$.

The desirability of providing an infant with feeds which are at least bacteriologically harmless needs no elaboration. To this end a number of differing methods have been employed but no general consensus of opinion appears to favour any one in particular. Those in current use range from the aseptic filling of presterilized or chemically disinfected bottles to the terminal heat treatment by hot water, steam at atmospheric pressure, or steam under increased pressure, of bottles already filled and with their teats in place.

As chemical disinfection cannot always be relied upon the method of choice must be heat in some form. Probably the simplest method would be to immerse the already filled bottles with their teats in place in a boiling water bath for about 20 minutes, but Lembcke (1941) found this to be unsatisfactory and responsible for an outbreak of infantile diarrhoea. At the other extreme would be a high-pressure steam sterilizer with its attendant difficulties in operation and maintenance, the possibility of chemical alteration of the food, and the high cost of installation.

Between these comes the simpler method of disinfection of the feed by steam at atmospheric pressure after it has been bottled and capped. Pasteurization has been the method of choice over many years for rendering milk safe for consumption (Topley and Wilson, 1964), and processing already bottled feeds in streaming steam is simply a modification of this. A technique for the purpose is described in this report.

\section{METHODS}

In the preliminary work an ordinary vertical laboratory type sterilizer supplied with steam from the hospital boilers was used. Later a Southern Cross sterilizercooler became available and was employed exclusively.

All temperatures were taken using an Ellab pyrometer, with the end of the thermocouple immersed in a milk sample.

The infant feeds were of two kinds:-

1 Carnation evaporated milk reconstituted to the formula currently used in the wards, viz.,

$$
\begin{array}{lllll}
\text { Carnation milk } & \ldots & . & 1 \mathrm{oz} . \\
\text { Water } & \ldots & \ldots & \ldots & 2 \mathrm{oz} . \\
\text { Sugar } & . & \ldots & . . & 1 \text { teaspoonful }
\end{array}
$$

2 Raw T.T. cow's milk unmodified

The following organisms were used to infect the feeds where required:-Str. faecalis, Str. haemolyticus, Staph. pyogenes phage type $42 D, E$. coli 0111, Salm. typhimurium, and $C$. albicans.

In each case the infecting dose was approximately $300 \times 10^{3}$ organisms per ml. of milk.

Volumes either of $4 \mathrm{oz}$. or $8 \mathrm{oz}$. of the infected samples were placed in feeding bottles which had previously been cleaned and then sterilized in a bench autoclave at a temperature of $121^{\circ} \mathrm{C}$. for 15 minutes. Pre-sterilized teats were contaminated with the test organism by allowing the infected feed to wet the inner surface and penetrate between this and the neck of the bottle. They were finally covered with a protective paper bag.

After processing the teats were removed with sterile forceps and each dropped into $100 \mathrm{ml}$. volume of digest broth. The cultures were incubated for 72 hours at $37^{\circ} \mathrm{C}$. and then subcultured on to a solid medium suitable for isolating the particular organism under examination. They were examined after a further 48 hours' incubation at $37^{\circ} \mathrm{C}$. The methods of examining the feeds are described below.

A number of different experiments were carried out on milk samples; for the sake of clarity each experiment with its results is described separately. Positive control cultures were put up on every occasion and satisfactory growths obtained.

\section{EXPERIMENT I}

Samples, each of $4 \mathrm{oz}$., of Carnation milk were infected with Str. faecalis and raised in a steamer to the temperatures shown in Table $\mathrm{I}$. These temperatures were not 
TABLE I

SAMPLES RAISED BUT NOT HELD AT VARIOUS TEMPERATURES

\begin{tabular}{ccl} 
Temperature $\left({ }^{\circ} \mathrm{C}.\right)$ & Milks & Teats \\
\hline 60 & $6 / 6$ & Not tested \\
70 & $22 / 25$ & $0 / 22$ \\
80 & $0 / 25$ & $0 / 25$ \\
90 & $0 / 25$ & $0 / 22$ \\
99 & $0 / 11$ & $0 / 11$
\end{tabular}

Numerator $=$ number from which test organism was recovered Denominator $=$ number of samples tested

held, and on being reached the bottles were removed and immediately plunged into cold running water.

\section{EXPERIMENT II}

As a Southern Cross 'sterilizer-cooler' had been ordered for a new milk kitchen it was thought desirable, while awaiting its delivery, to imitate as closely as possible the method by which it would be used and to try to ascertain the shortest exposure time which would destroy the test organisms.

The steam-operated laboratory type sterilizer was used, and 4 oz. samples of milk infected with Str. faecalis were placed in it and the lid left loose with the vent open. It was found that after the steam was turned on it took approximately 15 minutes for the samples to reach $100^{\circ} \mathrm{C}$. This temperature was held for various periods as shown in Table II. After processing $3 \times 10 \mathrm{ml}$. quantities of each test sample were added to equal volumes of double strength digest broth and incubated and subcultured as described above.

\section{TABLE II}

SAMPLES HELD AT $100^{\circ} \mathrm{C}$. FOR VARIOUS TIMES

\begin{tabular}{ccc} 
Holding Time (min.) & Milks & Teats \\
\hline 10 & $10 / 74$ & $6 / 69$ \\
15 & $0 / 39$ & $0 / 36$ \\
20 & $1 / 38$ & $0 / 35$ \\
25 & $7 / 59$ & $4 / 56$
\end{tabular}

Numerator $=$ Number from which test organism was recovered Denominator $=$ Number tested

Six of the milk and three of the teat failures which unexpectedly occurred after 25 minutes' steaming were all in the same batch and it is thought that a technical error in the laboratory may have been the cause.

\section{EXPERIMENT III}

The Southern Cross 'sterilizer-cooler' was now in operation so was used in place of the laboratory sterilizer.

The method of operation is as follows:-

After loading, closing the lid and drain cock, and setting the timing mechanism for the holding time desired, the apparatus is switched on.

1 Hot water to a depth of about 1 in. enters the chamber.

2 This is followed by steam which streams round the bottles finally raising them to approximately $100^{\circ} \mathrm{C}$.
3 When the chamber temperature reaches $100^{\circ} \mathrm{C}$. sensing device starts the timer and holds the temperature steady for the period which was pre-set.

4 At the end of the holding time steam is shut off ands cold water admitted. This mixes with the hot water of stage (1) and commences to cool the bottles. By repeatedo partial emptying and filling of the tank with cold waters the bottles and their contents are in about 10 minutesp cooled sufficiently for them to be put in a refrigerator for storage.

To ascertain whether even heating of the samples occurred in the chamber six thermocouples were introduced; one each of these was placed in an $8 \mathrm{oz}$. milk $\vec{\omega}$ sample and distributed to the four corners and centre of the chamber. The sixth remained free in the steam? Temperatures were read at intervals of one minute. The time controller was set for 25 minutes' holding time as recommended by the makers of Southern Cross equip ment. It was found that the timer came into operation when the steam temperature reached $98.5^{\circ} \mathrm{C}$., 11 minuteso from the start. At this moment the readings of the five thermocouples in the bottles varied between $77^{\circ} \mathrm{C}$. and $82^{\circ} \mathrm{C}$. Eleven minutes later these readings had evened out at $98^{\circ} \mathrm{C}$. and were held at about this temperature for a further 14 minutes. Table III shows a selection of thee temperature readings.

TABLE III

DISTRIBUTION OF TEMPERATURES

Minutes Thermocouples

\begin{tabular}{rllllllll} 
& $\begin{array}{l}\text { Back } \\
\text { Left }\end{array}$ & $\begin{array}{l}\text { Back } \\
\text { Right }\end{array}$ & $\begin{array}{l}\text { Front } \\
\text { Right }\end{array}$ & $\begin{array}{l}\text { Front } \\
\text { Left }\end{array}$ & Centre & $\begin{array}{l}\text { Free in } \\
\text { Steam }\end{array}$ & \\
\hline 1 & 22 & 22.5 & 21.5 & 21 & 18.5 & 18 & Off & \\
5 & 38.5 & 44 & 49 & $51 \cdot 5$ & 43 & 91 & & \\
11 & 77 & 78 & 82 & 81 & 81 & 98.5 & Starts & \\
15 & 93.5 & 94 & 95 & 94.5 & 95 & 98.5 & & \\
22 & 98 & 98 & 98 & 98 & 98 & 99 & & \\
36 & 98.5 & 98.5 & 98.5 & 98.5 & 98.5 & 99 & Stops & \\
& & & & & & & & \\
& & & & & & & &
\end{tabular}

The rate and evenness of heating having been ascertained $8 \mathrm{oz}$. milk samples were infected with a range of pathogenic organisms and processed according to the direc $\frac{D}{2}$ tions given by the makers of the equipment. Accordingly the timer was set for 25 minutes' holding time. In fact it was found that the 60-cycle American clock when used on a 50-cycle supply gave a holding time of 28 minutes so 5 that all other experiments were timed by stop watch.

After processing $3 \times 10 \mathrm{ml}$. volumes of each sample were added to $3 \times 10 \mathrm{ml}$. volumes of double strength digest broth and treated as described above. The results are shown in Table IV.

The results suggested that Staph. pyogenes was slightly more heat resistant under the conditions of the test than the other organisms. Those recovered were phage type $42 \mathrm{D}$, the same as had been used for infecting the milk and one unlikely to occur accidentally in a laboratory Although the test organism was seldom recovered, many samples showed a growth of aerobic spore-bearing bacilli of the subtilis group. 
TABLE IV

PROPORTION OF SAMPLES FROM WHICH THE TEST ORGANISM WAS RECOVERED

\begin{tabular}{lll} 
Organism & Milk & Teats \\
\hline Str. faecalis & $0 / 48$ & $0 / 48$ \\
Str. haemolyticus & $0 / 48$ & $0 / 48$ \\
Staph. pyogenes & $2 / 148$ & $3 / 148$ \\
E. coli 0111 & $0 / 48$ & $0 / 46$ \\
Salm. typhimurium & $0 / 72$ & $0 / 72$ \\
C. albicans & $0 / 48$ & $0 / 48$
\end{tabular}

Numerator $=$ Number of samples from which test organism was recovered

Denominator $=$ Number of samples tested

\section{EXPERIMENT $V$}

As the previous experiment suggested that Staph. pyogenes was somewhat heat resistant it was thought advisable to try and ascertain the proportion surviving after the standard heat treatment so membrane filter counts were undertaken.

As it is difficult to pass milk through a membrane filter without clogging it the method suggested by Fifield, Hoff, and Proctor (1957) was employed. Briefly this consists of taking $50 \mathrm{ml}$. of previously autoclaved $0.1 \%$ solution of Triton $\mathrm{X} 100$ at $45^{\circ} \mathrm{C}$. and pouring it and the milk sample simultaneously into the filtration apparatus. The membranes used were Millipore DA (Dairy Assay).

Staph. pyogenes $42 \mathrm{D}, 1,000$ per ml., were added to $8 \mathrm{oz}$. feeds of reconstituted Carnation milk and $1 \mathrm{ml}$. volumes were passed through the filter pad.

After processing for 25 minutes the filtration was repeated using $5 \times 1 \mathrm{ml}$. samples. In order to make the test as sensitive as possible the remainder of the $8 \mathrm{oz}$. feeds were each divided into 24 equal parts and each part added to an equal volume of double-strength digest broth. Thus the whole of the sample was cultivated. The results are given in Table $\mathrm{V}$.

Staphylococci were not isolated from the three teats employed in the experiment.

\section{TABLE V}

MEMBRANE FILTRATION COUNTS BEFORE AND AFTER PROCESSING FOR 25 MINUTES

\begin{tabular}{lcc}
$\begin{array}{l}\text { Membrane Counts }(\text { per } m l .) \\
\text { Before }\end{array}$ & $\begin{array}{c}\text { Bottle Counts after Heating } \\
\text { (Bottle }+/ \text { total bottles) }\end{array}$ \\
\hline Heating & After & \\
\hline 880 & Heating & \\
950 & 0 & $0 / 24$ \\
910 & 0 & $0 / 24$ \\
& 0 & $0 / 24$
\end{tabular}

\section{EXPERIMENT VI}

As the results of experiment $\mathrm{V}$ were completely negative it was thought worthwhile to try the effects of reducing the holding time and assessing the results by again dividing the sample into 24 parts and cultivating the whole of each. Again 8 oz. feeds were used and the test organisms were Str. faecalis and Staph. pyogenes 42D, their con-
TABLE VI

RESULTS OF VARYING PROCESSING TIMES

\begin{tabular}{cclcc}
$\begin{array}{l}\text { Holding } \\
\text { Time } \\
\text { (min.) }\end{array}$ & $\begin{array}{l}\text { No. of } \\
\text { Milk } \\
\text { Samples }\end{array}$ & $\begin{array}{l}\text { Test } \\
\text { Organism }\end{array}$ & $\begin{array}{l}\text { No. of Bottles } \\
\text { No. of Bottles } \\
\text { Tested }\end{array}$ & $\begin{array}{l}\text { No. of Teats } \\
\text { No. of Teats } \\
\text { Tested }\end{array}$ \\
\hline \multirow{2}{*}{20} & 3 & Staph. 42D & $0 / 72$ & $0 / 3$ \\
& 3 & Str. faecalis & $0 / 72$ & $0 / 3$ \\
15 & 6 & Staph. 42D & $0 / 144$ & $0 / 6$ \\
& 6 & Str. faecalis & $0 / 144$ & $0 / 6$ \\
10 & 3 & Staph. 42D & $0 / 72$ & $0 / 3$ \\
& 3 & Str. faecalis & $0 / 72$ & $0 / 3$ \\
5 & 3 & Staph. 42D & $0 / 72$ & $0 / 3$ \\
& 3 & Str. faecalis & $0 / 72$ & $0 / 3$
\end{tabular}

centrations being $300 \times 10^{3}$ per ml. of feed. Table VI shows the results.

\section{EXPERIMENT VII}

As Staph. pyogenes and Str. faecalis appeared from the previous experiment to have been eliminated by five minutes' holding time further tests were carried out under similar conditions using the same organism and in addition Strep. haemolyticus, E. coli 0111, Salm. typhimurium, and Candida albicans. The results are shown in Table VII.

\section{TABLE VII}

EFFECT OF FIVE MINUTES' EXPOSURE ON VARIOUS INFECTING ORGANISMS

\begin{tabular}{lcc}
$\begin{array}{l}\text { Infecting } \\
\text { Organism }\end{array}$ & $\begin{array}{l}\text { No. of Samples } \\
\text { Tested }\end{array}$ & $\begin{array}{l}\text { No. of Bottles still Infected/ } \\
\text { No. of Bottles Tested }\end{array}$ \\
\hline Strep. faecalis & 12 & $1 / 288$ \\
Strep. haemolyticus & 12 & $0 / 288$ \\
Staph. pyogenes 42D & 12 & $0 / 288$ \\
E. coli 0111 & 12 & $0 / 288$ \\
Salm. typhimurium & 12 & $0 / 288$ \\
C. albicans & 12 & $0 / 288$
\end{tabular}

\section{EXPERIMENT VIII}

Although experiments VI and VII suggested that the test organisms could be eliminated satisfactorily after five minutes' exposure to steam at atmospheric pressure it was found, as was expected, that spore-bearing organisms were not destroyed by these conditions. Consequently it was thought desirable to ascertain whether or not a substantial reduction in their numbers had been achieved.

\section{TABLE VIII}

REDUCTION IN NUMBER OF SPORE-BEARING ORGANISMS Sample No.

Organisms per $\mathrm{ml}$.

Before Processing After Processing

\begin{tabular}{rrr}
\hline 1 & 1,470 & $0 \cdot 5$ \\
2 & 1,270 & $1 \cdot 5$ \\
3 & 480 & 0 \\
4 & 1,800 & 6 \\
5 & 870 & 14 \\
6 & 580 & 14 \\
7 & 125 & 2 \\
8 & 1,770 & 9 \\
9 & 1,110 & 16 \\
10 & 1,033 & 27
\end{tabular}


Samples of antibiotic-free raw T.T. cow's milk, each of $8 \mathrm{oz}$., were used and total counts made on membrane filters before and after processing for five minutes. The samples were not artificially infected. In all 10 samples were tested and the results shown in Table VIII indicate that the numbers were in fact greatly reduced.

\section{DISCUSSION}

If the necessity for terminal heat treatment of milk feeds is accepted, and this acceptance is not universal (Farquhar, Gould and Schutt, 1965), then the simplest method which will produce an inocuous feed is probably the best. For many years pasteurization has been recommended for rendering milk safe for human consumption. Two methods have been employed in the past: the holder method which entails holding the milk for $\mathbf{3 0}$ minutes at a temperature between $63^{\circ} \mathrm{C}$. and $66^{\circ} \mathrm{C}$. and the high-temperature, short-time method which necessitates heating the milk to $72^{\circ} \mathrm{C}$. for 15 seconds. In both cases the milk must be rapidly cooled to $10^{\circ} \mathrm{C}$. or lower.

Pyrometer tests using the five-minute holding time described in experiments VI and VII indicate that an $8 \mathrm{oz}$. feed is held at $72^{\circ} \mathrm{C}$. or above for four minutes, a $4 \mathrm{oz}$. feed for four and a half minutes, and a $2 \mathrm{oz}$. feed for five minutes so that an ample margin of safety should be ensured. That this is correct is shown by the results given in Table VII.

Spore-bearing organisms are not entirely eliminated but their numbers are reduced to reasonable proportions as shown in Table VIII. The American Academy of Pediatrics (1964) suggest that a colonycount should not exceed 25 organisms per $\mathrm{ml}$. and that these should only be spore bearers. This standard has been attained. Providing the feed is cooled and refrigerated immediately after heating these organisms should cause no damage or spoilage, although if held at room temperature they will multiply rapidly (Smith, Finley, Wright, and Louder, 1948).

The effect of heat treatment on the heat-labile nutrients in infant formulae has been investigated by Hodson (1949). Using ascorbic acid, thiamine, and lysine as indicators, he found that $95 \%$ of the ascorbic acid, $91 \%$ of the thiamine, and $100 \%$ of the lysine were present after samples had been held at $100^{\circ} \mathrm{C}$. for 15 minutes. When held at $110^{\circ} \mathrm{C}$. for 10 minutes the results were almost the same.

It must also be remembered that condensed milk and powdered milk may already have been exposed to temperatures as high as $116^{\circ} \mathrm{C}$. and $170^{\circ} \mathrm{C}$. respectively, so that pasteurization is unlikely to을 cause appreciable further deterioration (Davis, $\underset{\vec{c}}{\vec{\rho}}$ $1963 \mathrm{a}$ and b).

The makers of Southern Cross equipment recommend a holding time of 25 minutes. Using this $\frac{\bar{c}}{\bar{c}}$ period a complete cycle takes approximately 11-12 $\vec{\sigma}_{\bar{\sigma}}$ minutes' heating up time until the controller starts, 25 minutes holding, and 10 to 12 minutes cooling before the bottles can be removed to a refrigerator, $\vec{O}$ in all about 46 to 49 minutes. From our results it would seem that a substantial reduction could safely $\vec{\omega}$ be made. A holding time of 10 minutes (double the? five minutes found adequate) would reduce the total? cycle time to about 31 to 34 minutes and even greater $\overrightarrow{0}$ reduction could be achieved if an improved method + of heating up and cooling could be designed. One $\omega$ other point should be made. It is little use producing ${ }_{\circ}$ a sterile or bacteriologically harmless feed in the milk kitchen if subsequent treatment during distri- $\vec{c}$ bution and presentation to the infant render it once again potentially dangerous to the unfortunate recipient. It is recognized that this can and oc- $\mathscr{8}$ casionally does happen, and for this reason the teat $\%$ must remain covered until the feed is actually given.

Our thanks are due to Dr. J. Moseley, paediatrician at Portsmouth, for permission to make use of the Southern

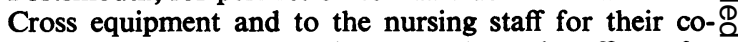
operation; to Mr. J. Robson, work study officer, for $\overrightarrow{\vec{A}}$ much information about the equipment; to Mr. Wood-응 cock, of General Milk Products Ltd., for kindly obtaining reprints and other information from the United States at the beginning of the work; and to the Wessex Regional Hospital Board for a research grant.

\section{REFERENCES}

American Academy of Pediatrics (1964). Standards and Recommendations for Hospital Care of Newborn Infants. Evanston, Ill.

Davis, J. G. (1963a). Dictionary of Dairying, 2nd ed., p. 280. Hill, 윽 London.

- (1963b). Ibid., p. 719.

Farquhar, J. W., Gould, J. C., and Schutt, W. H. (1965). Lancet, 1, ․ㅡ․

Fifield, C. W., Hoff, J. E., and Proctor, B. F. (1957). J. Dairy Sci., Љ 40,580 .

Hodson, A. Z. (1949). J. Amer. diet. Ass., 25, 119.

Lembcke, P. A. (1941). Amer. J. Hyg., 33 (Sect. A), 42.

Smith, F. R., Finley, R. D., Wright, H. J., and Louder, E. A. (1948). $J$. Amer. diet. Ass., 24, 755.

Topley, W. W. C., and Wilson, G. S. (1964). Principles of Bacteriology and Immunity, edited by G. S. Wilson and A. A. Miles, 5th ed. Arnold, London.

Wright, J. (1951). Brit. med. J., 2, 138. 